International Journal of Engineering \& Technology, $7(4.38)(2018)$ 1154-1157
International Journal of Engineering \& Technology
SPC
Website: www.sciencepubco.com/index.php/IJET
Research paper

\title{
Franz Kafka's Novel der Prozess (The Trial) As A Novel About Creative Endeavor, Choice and Faith
}

\author{
Evgenii Sergeyevich Kunavin ${ }^{1 *}$ \\ ${ }^{1}$ Affiliation of the first author FSBEI of HE "Moscow Pedagogical State University”, 1/1 M. Pirogovskaya Str., Moscow, \\ *Corresponding author E-mail: evgenii_kunavin@mail.ru
}

\begin{abstract}
In this article, the author discusses the topic of adequate interpretation of F. Kafka's novel The Trial, one of the most well-known works of literature of the early 20th century, this topic being very relevant for contemporary literature studies. The introduction states the purpose of the article, and points out that the theme of creative pursuits, which is touched upon in the writer's diaries and letters, is one of the main topics that help understand the environment in which the novel was created. The principal part of the paper reveals approaches used to analyze the novel. Additionally, the article discusses records from the writer's diary and letters; shows the direct link between the works and the biography of the Prague writer. The article presumes that the novel models a real-life situation. It argues S. Kierkegaard had an impact on F. Kafka's writing, and uncovers a link between works of the Danish philosopher and the emergence of the novel. Moreover, the paper draws a conclusion on the role that F. Kafka's lover, F. Bauer, played in creating The Trial, proposes a possible plot of the novel and summarizes observations on the work. In conclusion, the article speaks about the results of the "modeling" that F. Kafka obtained, and about the influence of that novel and S. Kierkegaard's ideas on the latter part of the Prague writer's career.
\end{abstract}

Keywords: Franz Kafka, Sфren Kierkegaard, The Trial, analysis, diary, letters, internal conflict, faith, choice, vocation.

\section{Introduction}

Nearly since its first publication in 1925, F. Kafka's incomplete novel, which is considered a pinnacle of world literature, has been in the focus of discussions by literature scholars. The novel that saw the light of the day only after the writer's death, a novel that has no detailed author's comment and an order of chapters generated a large number of various interpretations. Among them, there have been consistent and logical ones, and there have been others, which were especially sophisticated and could not withstand any serious criticism. Understanding clearly the main idea of the novel is necessary for a number of reasons, both historical, literary, theoretical (identifying the novel's place in the general literary process of the early 20th century, the influence of the author's ideas on further development both of Germanlanguage and world literature, etc.), and applied ones, for instance, for more effective teaching of F. Kafka's creative oeuvre in general and the novel The Trial in particular at educational institutions. Only an adequate perception of the novel can promote development of the axiological and conceptual field of every student, which will contribute to reinforcement of the positions of the axiological approach in education $[1,18]$.

Aside from diversity in interpretations, modern Kafka studies know multiple academic approaches to the study of the novel. They include theological and existential, individual and psychological approaches, approaches from the standpoint of political, social or literary studies, culture and history, social psychology, etc. [11].

The purpose of this article is to consider the theme of creative endeavors in F. Kafka's diaries and letters as the key one in understanding the creation of The Trial. By now, multiple explanations have been proposed for the key idea of the novel. Among the central ones, we can cite the following: search for God, relations with the fiancée and the topic of a "separate man." However, the theme of creative endeavors in those interpretations is either not treated at all or is mentioned only in passing $[3,6]$, despite the fact that the topic of "writing" dominates the diaries and correspondence with F. Bauer between 1912 and 1915. In addition, those interpretations do not take into account the circumstance that the issue of "writing" was becoming increasingly more intense in that period and disappeared from the writer's epistolary legacy only after his unsuccessful attempt to write the novel.

\section{Research methods}

This article uses existential, individual and psychological, as well as literary (biographical, comparative and hermeneutic methods) approaches. Their choice is determined by the following factors. First, in the opinion of the author of this article, the novel The Trial is largely connected to ideas of the Danish philosopher S. Kierkegaard, whose unmistakable influence F. Kafka felt. Modern Kafka studies do not doubt the Kierkegaard "trace" in F. Kafka's minor prose. For instance, H. Miethe showed clearly in her work the link between certain novellas of the Prague writer and the Copenhagen thinker's work The Sickness unto Death [12]. Second, a detailed analysis of diaries and letters of the Germanlanguage writer does not leave a shadow of a doubt in F. Kafka's creative legacy being manifestly egocentric. Such is the opinion expressed by M. Reich-Ranicki, a leading German literary critic of the second half of the 20th and the early 21 st century [5]. 
Therefore, it is no surprise that the author of The Trial was reflecting mainly on his own existence.

\section{Findings}

Obviously, before the creation of the novel and during its writing, the key topic of F. Kafka's diaries and correspondence was his own writing. From 1911 to 1915, one can find dozens of cases when creative process is mentioned, and it is mentioned both with regard to its positive, creative, side, and also to its negative, destructive, aspect. Especially characteristic in that respect are the letters to F. Bauer written in November 1912, in which F. Kafka worded his life program: "My mode of life is devised solely for writing" [8]. We also should recall his diary record dated June 21, 1913: "The tremendous world I have on my head. But how free myself and free it without being torn to pieces. And a thousand times rather be torn to pieces than retain it in me or bury it. That, indeed, is why I am here, that's is quite clear to me" [8]. There are many such characteristic fragments in F. Kafka's legacy, which refer the reader to creative pursuits; one does not have to look for them specially — it suffices to reread letters to Felice written before the breakup of the first engagement.

Those two and a half years in the writer's life (from August 1912 to January 1915) were different from others from the standpoint of the author's extremely unstable psychological condition. If the year 1912, which was marked by F. Bauer coming into the writer's life, was a year of creative breakthrough and awareness of his own creative power (the novellas Das Urteil (The Judgment) and Die Verwandlung (The Metamorphosis) were written), in 1913 and 1914, cyclical changes of mood were taking place: during "good" phases, F. Kafka was full of vigor and desire to create, he believed in his own powers and destiny, he wrote the novel Der Verschollene (Amerika); during his "bad" periods, he was sinking deeply into depression, doubted his own talent and was feeling the entire "hell" of writing on himself, as he once put it in a letter to M. Brod. It should be noted that periods of depression did not coincide with periods of quarrels with his lover, which means we cannot speak about a direct link between the creative process and love relations. F. Kafka's biographers [15] note that by August 1912 a situation had emerged in which Kafka's creative career was lacking just one small thing to flourish - some spiritual "shocks," which would become a "trigger" for a real breakthrough. Moreover, in the opinion of some scholars, such as Canetti, Deleuze, Guattari and Baumgart, Kafka used his correspondence with F. Bauer for "sharpening his pen" [15]. He realized nearly right from the start that his correspondent was a very mediocre reader, not entirely devoid of taste, but lacking in insight. However, that did not prevent Kafka from speaking about literature. Or, to be more precise, about his literature. He was not particularly interested in his fiancée's viewpoint and did not consult her. He was not particularly interested in her opinion about his writing, - it was important for F. Kafka to speak out himself, because, when he uttered the most important and essential things, he was doing soul-searching, using that "one-sided" communication to perform complicated forms of thinking.

A similar case occurred in the creative life of S. Kierkegaard. A biographer of the Danish philosopher wrote: "It was Regina who put a pen into his hand, and since then he played out his relationship with her from all conceivable viewpoints, liberating himself from the material during the act of writing" [14]. A letter as an instrument of thinking is one of many points where F. Kafka and S. Kierkegaard "overlap."

Attitude to literature can be called a second such point. The Prague author, who had a rich imagination and a desire to create since his childhood, only at the age of 25 started to think seriously about literature as his vocation and the only meaning of life [16]. He acknowledges that from now on his life belongs to writing utterly and completely. However, at the same time, he also had to confront the fact that the nature of creative activities is an insolvable mystery for the human being; the writer speaks about an "invisible power" that dominates over him, and its dominance is truly boundless. The most serious conflict that F. Kafka was faced with on the "thorny path" of his creative pursuits was the impossibility of merging everyday life (work, family, etc.) and writing. Naturally, that conflict is nothing new - it was actively treated by many Romantic writers, such as, for instance, H. von Kleist, F. Grillparzer, E.T.A. Hoffmann, L. Tieck and many others. It is also an important thing that it was the abovementioned German novelists who were F. Kafka's favorite reading. With two of them, Kleist and Grillparzer, Kafka felt "kinship" and even understood H. von Kleist's choice - suicide - when he found himself in a similar situation (a letter to Felice dated September 2, 1913).

The Danish philosopher, becoming aware of his vocation, abandoned everything that could interfere with his writing: his lover, friends, society, etc. F. Kafka intended to act in a similar way; however, internal conflicts and contradictions prevented him from translating his plans into practice for a long time. Internal tension in addressing the "creative issue," the search for "likeminded people" in the history of philosophy and literature, complaints of the unsolved conflict between "the office and writing," which disappeared after the "unsuccessful" completion of The Trial, suggest that the novel was a model of the situation in which the writer had found himself. By recreating that conflict in a work of fiction, F. Kafka was trying to address his most complicated, profound issues that had tormented him over a few years. Jurg Amann wrote about Kafka's attitude to his own writing: "er [Каfка] war also gleichzeitig Subjekt und Objekt seines Schreibens" ("he [Kafka] was simultaneously the subject and the object of his writing") [2].

It is a fact established in psychology long ago that for the creative personality of a writer, the world that matters for a particular person, with his abilities, experience, area of activities, lies no doubt in a work of fiction within which he can, by building the fictional space of the text in a special way, realize or approach realization of the basic existentials of his personality, i.e. a writer's existential intention is directed to a large extent to the realization of his basic existentials within the framework of his oeuvres, because their realization in real life is often impossible [17]. The terms "existential" means a method of human existence, the foundation of a human's being [4].

One of the profound issues that the writer was striving to address was making the final decision in favor of one side in the "conflict": to live like an ordinary person or to devote his whole life to creative pursuits. F. Kafka was conscious that since a human being can think and be aware of his own being, and, consequently, become responsible for his own being, he must also be conscious of himself and be responsible for himself, if he wants to become himself. Becoming himself meant for him one thing only - devoting his whole self to serving literature, sacrificing every minute of his life on her altar. To address that issue, not only did he have to dedicate all of himself, doing his utmost in making that commitment, but he had to literally strain his whole being, including all physical and psychological capabilities. It is a well-known fact that only that way real works of art can be created [13].

The headline of the article says that The Trial is a novel about creative endeavor, choice and faith. If everything is clear with creative endeavor and choice, as an effect of a simulated situation, the issue of faith requires separate consideration. Faith is one of cornerstones in S. Kierkegaard's writings. It suffices to cite his principal works - The Sickness unto Death and Fear and Trembling. If the Danish thinker perceived it exclusively in the religious sense, because it is directly related to Christian faith, in F. Kafka's case that definition of faith is not relevant, because there is no direct reference to a particular doctrine or religious denomination. F. Kafka, as a person who was raised amidst a multicultural environment, brought into his novel, making it an "off-the-stage" character, not just some specific god of a particular 
denomination, but a generalized image of the Law; especially clearly it is revealed in the set-in miniature (V.G. Zusman's term [19]) Before the Law, which is close to a parable in its genre. In doing so, Leskowa notes, F. Kafka creates "a special type of parables... shifting the 'center of gravity' from the external world to the internal one, which opens up a prospect of existential reading of Kafka's parables" [10]. The Law itself, for the sake of convenience, can be defined as the Absolute. An even more accurate definition of the "supreme power" is revealed in Kafka's words: "for every person there is their own Law". One can see that it is not the religious side of the matter that is being discussed here

In the opinion of the author of this article, The Trial is a novel telling a story of a person seeing the feeling of his vocation waking up inside him. It is a novel that describes how difficult it is for that person to acknowledge his own gift; gift in a sense that his exceptional talents and abilities are not just a fluke, a fortuitous turn of events, an evolutionary "bonus," but an endowment, which a person receives from supreme powers. It is a novel telling how difficult it is to believe in oneself and to go down one's own, very difficult but also very interesting, way.

The plot of the novel, if we look at it from that side, will be perceived like this: one day, a man starts to be conscious of his gift (and it also carries a big responsibility for the possessor); unrealized talents generate the feeling of guilt which starts to poison the man's life from now on; that internal conflict requires resolution; the first, and the most natural thing that the man does is indignation - he tries to get back to the former state of calm, ignoring the gradually emerging awareness of his gift; the attempt at indignation falls flat; the period of "strife" starts, which involves the man so much that he no longer can ignore the internal conflict or resolve it "in one fell swoop." Gradually, as his selfawareness grows, he is faced with a choice: either to devote himself fully to his gift, to acknowledge his "guilt", or to continue his futile and exhausting struggle that has a few equally fruitless variants of development. To resolve to take up the first variant, he should make a "leap of faith," because acknowledging his gist leads to a breakup with the external world - a talent requires great sacrifice from a gifted person; doubts that plague a person prevent him from making a fully valid choice: he seems to understand everything but he "stands still" in the pole position, and instead of taking a risk and believe, he "snatches at life with all his hands" until the last moment - that irresolution warrants the ridiculous behavior of those in attendance and the hero's repentance at the end of the novel.

As the novel unfolds, Josef $\mathrm{K}$. is facing despair according to Kierkegaard. The Danish thinker himself thought that there were very few people who were conscious of their spiritual destiny: "There are very few men who live even only passably in the category of spirit; yea, there are not many even who merely make an attempt at this life, and most of those who do so, shy away" [9]. However, $\mathrm{K}$. is one of them. It takes him just one year to complete the full cycle, to go through all the stages of his trial, from "indignation" and "despair" to "understanding", and still, at the very end, he lacks the movement of faith (S. Kierkegaard's term) to believe the absurd and to recognize that an unknown powerful Law has the supreme right. In his own opinion, K. fails the test; however, the reader cannot help acknowledging he has moved to a different spiritual plane. $\mathrm{K}$. became aware of the trial, but he was unable to make a "leap of faith" (S. Kierkegaard's term). He could not fully believe that a court pardons those whom it accuses: “...punishment, solution and salvation approached from afar...My feeling of happiness lay in the fact that I welcomed so freely, with such conviction and such joy, the punishment that came, a sight that must have moved the gods, and I felt the gods' emotion almost to the point of tears" (Diaries, dated October 20, 1921).

\section{Conclusion}

The same conclusion had been reached by 1915 also by F. Kafka, who left the novel incomplete after a new attempt at writing the ending, and he did not go back to the issue of creative process over the next few years. A mental experiment generated a wonderful work of literature of international importance, but it ended in a personal failure for the author. It is a known fact that in 1917 F. Kafka resigned from his office position and devoted himself to writing; however, it was done quite late in life, when his physical health had been seriously undermined, and he had only a few years to live (seven years). An unknown powerful court punished him, and "red tape" did its work: the writer was "ground between millstones of creation and the office" [7]. Later on, beginning from 1917, F. Kafka would be actively interested in the theme of a relationship between an individual and the Absolute; therefore, one can say with conviction that infatuation with $\mathrm{S}$. Kierkegaard's works and writing the novel The Trial produced a significant impact on the entire latter period in the writer's career.

\section{Acknowledgement}

I wish to express my sincere gratitude to staffers of the World Literature Chair of the Philology Institute of the Moscow Pedagogical State University, and also personally to I.V. Uskova, Senior Fellow of the Russian Academy of Education, for assistance in the collecting necessary material and for editing this article.

\section{References}

[1] O.M. Aleksandrova, I.P. Vasilevykh, Yu.N. Gosteva, et al., Upon the Problem of the Definition of "Training Text" in the Conditions of Information and Educational Environment, Venezuela, Caracas. Espacios 38(4) (2017).

[2] J. Amann, A.T. Schaefer, Kafka: Wort-Bild-Essay, Hamon Verlag, Innsbruck, 2000

[3] E. Canetti, Kafka`s Other Trial: The Letters to Felice, Schocken Books, New York, 1974.

[4] A.S. Gagarin, Ekzistentsialy chelovecheskogo bytiya: odinochestvo, smert', strakh (ot Antichnosti do Novogo vremeni) [The existentials of human existence: loneliness, death, fear (from Antiquity to the New Times)], Istoriko-filosofskii aspekt, Doctoral thesis, UGU im. A.M. Gor'kogo, Ekaterinburg, 2002.

[5] V. Hage, Der Dichter unserer Zukunft, Der Spiegel 40 (2014) 116124.

[6] M.-C. Holz, M. Steinmetz, C. Beier, Der Prozess vom Franz Kafka: Eine Analyse aus drei Blickwinkeln, Science Factory, Norderstedt, 2013.

[7] F. Kafka, Letters to Felice, Schocken Books, New York, 1973.

[8] F. Kafka, The Diaries of Franz Kafka (1910 - 1924), Schocken Books, New York, 1976

[9] S. Kierkegaard, The Sickness unto Death, Princeton University Press, Princeton, 1941.

[10] E.V. Leskowa, Zhanrovaya spetsifika pritchi i paraboly v tvorchestve F. Kafki i F.M. Dostoevskogo: ekzistentsial'nyi aspekt [Genre specifics of the parable and parabola in the works of $F$. Kafka and F.M. Dostoevsky: the existential aspect], $\mathrm{PhD}$ thesis, BFU im. I. Kanta, Kaliningrad, 2015.

[11] T.V. Luppova, Lingvostilisticheskie parametry prostranstvennoi perspektivy v khudozhestvennom tekste: na materiale romanov $\mathrm{F}$. Kafki [Linguistic-stylistic parameters of spatial perspective in the artistic text: on the material of F. Kafka's novels], PhD thesis, UGPU, Ekaterinburg, 2003.

[12] H. Miethe, Sören Kierkegaards Wirkung auf Franz Kafka Motivische und sprachliche Parallelen, Tectum Verlag, Marburg, 2006.

[13] M. Reich-Ranicki, Romane von gestern heute gelesen (1918 1933). Die Lüge als Weltordnung, Burger, H. Frankfurt am Main: Fischer Taschenbuch Verlag, 2011, 40-46.

[14] P. Rohde, Seren Kirkegor sam svidetel'stvuyushchii o sebe i o svoei zhizni [Seren Kirkegor self testifies about himself and about his life], Ural LTD, Chelyabinsk, 1998. 
[15] R. Stach, Kafka: the decisive years, Houghton Mifflin Harcourt, Orlando, 2005.

[16] R. Stach, Kafka, the early years, Princeton University Press, Princeton, 2017.

[17] V.I. Tkachenko, Sposoby realizatsii ekzistentsial'noi intentsii v individual'nom povestvovatel'nom diskurse Frantsa Kafki [The ways of realization of existential intention in individual narrative discourse of Franz Kafka], PhD thesis, BFU im. I. Kanta, Kaliningrad, 2013.

[18] I.V. Uskova, Didakticheskie trebovanija $\mathrm{k}$ domashnej uchebnoj rabote $\mathrm{v}$ uslovijah informacionno-obrazovatel'noj sredy [Didactic requirements for home teaching work in conditions of information and educational environment], Soderzhanie i metody obnovljajushhegosja obrazovanija: razvitie tvorcheskogo nasledija I.Ja. Lernera: Sbornik nauchnyh trudov Mezhdunarodnoj nauchnoteoreticheskoj konferencii, posvjashhjonnoj 100-letiju so dnja rozhdenija I.Ja. Lernera (10-12 oktjabrja 2017 g.). Vol. II., FGBNU "Institut strategii razvitija obrazovanija RAO", Moskva, 2017.

[19] V.G. Zusman, Khudozhestvennyi mir Frantsa Kafki: malaya proza romany [The artistic world of Franz Kafka: small prose and novels] Doctoral thesis, NGLU im. N.A. Dobrolyubova, Nizhnii Novgorod, 1997. 